\title{
Protein enrichment of cassava pulp by solid-state fermentation using Aspergillus niger
}

\section{Yafetto $L^{*}$}

Department of Molecular Biology and Biotechnology, School of Biological Sciences, College of Agriculture and Natural Sciences, University of Cape Coast, Cape Coast, Ghana

Yafetto L 2018 - Protein enrichment of cassava pulp by solid-state fermentation using Aspergillus niger. Studies in Fungi 3(1), 7-18, Doi 10.5943/sif/3/1/2

\begin{abstract}
This study aimed to assess protein enrichment of sterile and non-sterile cassava pulp using four strains of Aspergillus niger - AN1, AN2, AN3, AN4. First, studies were conducted to evaluate nutritional requirements of $A$. niger strains and their suitability for protein enrichment of cassava pulp. Second, sterile and non-sterile cassava pulps were inoculated with spores of A. niger strains and incubated under conditions of solid-state fermentation for 8 days using standard methods. Protein contents of sterile and non-sterile cassava pulps were determined by the Kjeldahl method. Initial nutritional requirements studies showed that $A$. niger strains grew at rates between $2.0 \mathrm{~cm}$ and $8.5 \mathrm{~cm}$ over 10 days on potato dextrose agar medium of different $\mathrm{pH}$. The dry weight of mycelia of $A$. niger strains varied in liquid media separately supplemented with different concentrations of thiamine, ammonium nitrate and sodium chloride. A. niger strains also showed different levels of sporulation when cultured in growth media supplemented with different concentrations of sodium chloride. Increases in protein contents of sterile cassava pulp by AN1, AN2, AN3 and AN4 were 15.65\%, $22.61 \%, 18.30 \%$ and $19.13 \%$, respectively. On non-sterile cassava pulp, the increases in protein content by AN1, AN2, AN3 and AN4 were 15.40\%, 21.54\%, 10.80\% and 3.85\%, respectively. A. niger strain AN2 was the most suitable strain for the enrichment of protein content of cassava because it sparsely produced spores, it had the highest mycelial growth and resulted in the greatest increase in protein content of both sterile and non-sterile cassava pulp.
\end{abstract}

Keywords - agro-industrial wastes - livestock feed - nutrient improvement - solid-substrate fermentation

\section{Introduction}

The significant increase in demand for livestock products in developing countries has resulted in subsequent increase in production and supply of animal feed. Of particular interest is the exploitation of large quantities of agro-industrial wastes, such as cassava (Manihot esculenta), coffee (Coffea arabica), maize (Zea mays), oil palm (Elaeis guineensis), pineapple (Ananas sativa), potato (Ipomoea batatas), rubber (Hevea brasiliensis) and sugarcane (Saccharum officinarum), that are dumped, allowed to rot in the environment, and usually accompanied by smelly odours (Ezekiel \& Aworh 
2013). Bioconversion of these low-nutrient agro-industrial wastes into potential protein-enriched fermented animal feed has solved the environmental nuisance created by their disposal, a strategy that has gained prominence in recent years (Panday \& Soccol 2000, Panday et al. 2000, Soccol \& Vandenberghe 2003).

Cassava is one of the most important tuber crops that is grown largely in the tropics - Africa, Central and South America - and consumed on a large scale (Bayitse et al. 2015). Although the cassava tuber has protein content less than $3.0 \%$, it yields the highest amount of starch compared to any other tropical tuber crop (Grace 1977).

In Ghana, Nigeria and other countries in West Africa, cassava is processed into products such as cassava grits (gari), boiled, pounded cassava paste $(f u f u)$, dried cassava flour (kokonte), cassava biscuits, starch, tapioca, among others. The resultant wastes that are generated from these cassava processes are rarely used for any meaningful product because of their low protein, high crude fiber and cyanide contents (Akinrele 1967, Onilude 1996, Iyayi \& Losel 2001).

Meanwhile, in Ghana alone, large quantities of cassava waste, particularly cassava peels, from starch and gari-processing factories can be converted into protein-rich animal feed for the poultry and fish industries (Bayitse 2015). This process of conversion of cassava peels into useful products is possible since these wastes serve as suitable substrates on which microorganisms can grow to enrich the protein content through solid-state fermentation, a process that uses natural heterogeneous materials containing complex polymers like lignin, pectin, and lignocellulose (Akinrele 1967, Tengerdy 1985, Kumar 1987, Oriol et al. 1988a, Agosin et al. 1989, Roussos et al. 1993, Balagopalan 1996, Onilude 1996, Iyayi \& Losel 2001, Duru \& Uma 2003, Correia et al. 2007, Gélinas \& Barrette 2007, Bayitse et al. 2013, Ezekiel \& Aworh 2013, Aggelopoulos et al. 2014). Despite the abundance of cassava waste in Ghana, the application of microorganisms, particularly fungi, to enhance its nutritional and economic values to feed livestock and, consequently, increase farming profitability, and provide jobs for the masses is yet to attract serious attention (Bayitse et al. 2015). Additionally, there is very minimal biotechnological application of fungi in the production of protein-enriched agroindustrial products in Ghana. This present study therefore aimed to assess the application of A. niger in enriching protein content of cassava pulp by solid-state fermentation. This process of solid-state fermentation provides a means of converting cassava waste into useful feed for the production of fish and poultry.

\section{Materials \& Methods}

\section{Aspergillus niger and Cassava}

Four A. niger strains (AN1, AN2, AN3, and AN4) were obtained from the Mycology Laboratory of the Department of Botany, University of Ghana, sub-cultured on potato dextrose agar (PDA) medium (200 g Irish potato; $20 \mathrm{~g}$ dextrose; $20 \mathrm{~g}$ agar; $1000 \mathrm{ml}$ distilled water; autoclaved at a pressure of $1.1 \mathrm{~kg} / \mathrm{cm}^{2}$ at $121^{\circ} \mathrm{C}$ for 15 minutes) at $25^{\circ} \mathrm{C}-30^{\circ} \mathrm{C}$ for 7 days, and preserved as stock cultures on slants in McCartney bottles at $4^{\circ} \mathrm{C}$. Fresh tubers of cassava used for protein enrichment studies were obtained from the local Ghanaian market.

\section{Mycelial growth}

Petri dishes with solidified PDA medium were upturned and two diameters were drawn at right angles to each other at the bottom of the lower receptacle. Still upturned, the lower receptacle of the Petri dish was gently lifted and the surface of the solid PDA medium was inoculated with 3-mm inoculum disc of 7-day old $A$. niger cultures at the point of intersection of the two diameters using a 10 -mm sterile cork borer. The Petri dishes were incubated in the upturned position at $30^{\circ} \mathrm{C}$. Linear mycelial growths were measured along the two predetermined diameters at 2-day intervals until day 10. 


\section{Growth of $A$. niger strains on media with different $\mathrm{pH}$}

To assess vegetative growth of $A$. niger strains at different $\mathrm{pH}$ levels, $100 \mathrm{ml}$ of sterile potato dextrose broth (PDB) medium (200 g Irish potato; $20 \mathrm{~g}$ dextrose; $1000 \mathrm{ml}$ distilled water and autoclaved at a pressure of $1.1 \mathrm{~kg} / \mathrm{cm}^{2}$ at $121^{\circ} \mathrm{C}$ for 15 minutes) was adjusted to different $\mathrm{pH}$ levels with Clark and Lubs (1917a, 1917b, 1917c) and McIlvaine (1921) stock buffer solutions. A volume of 30-ml aliquots of each PDB buffer-amended growth media was dispensed into 250-ml Erlenmeyer flasks in triplicates, inoculated with 3-mm culture disc of $A$. niger strain AN1 and incubated at $30^{\circ} \mathrm{C}$ for 8 days. Mycelia mats were harvested on 9-cm Whatman's No. 1 filter papers that had been predried and pre-weighed for 24 hours at $80^{\circ} \mathrm{C}$. The pre-weighed filter paper together with the harvested mycelia mats were dried to constant weight in hot air oven for 24 hours at $80^{\circ} \mathrm{C}$ and placed in a vacuum desiccator containing anhydrous calcium chloride.

The dry weight of mycelium was determined as follows:

Dry weight of mycelium $=$ Total weight $($ pre-dried filter paper + mycelium $)-$ weight of pre-dried filter paper

The initial and final $\mathrm{pH}$ levels of each culture medium were recorded. The experiment was repeated using A. niger strains AN2, AN3 and AN4.

\section{Determination of vegetative growth of $A$. niger strains on media with different concentrations of thiamine}

One liter of synthetic basal medium (Glucose, $30.0 \mathrm{~g}$; Potassium dihydrogen phosphate $\left(\mathrm{KH}_{2} \mathrm{PO}_{4}\right), 1.0 \mathrm{~g}$; Magnesium sulphate $\left(\mathrm{MgSO}_{4} .7 \mathrm{H}_{2} \mathrm{O}\right), 0.3 \mathrm{~g}$; Minor Element Solution, $0.25 \mathrm{ml} ; 1000$ $\mathrm{ml}$ sterile distilled water) was prepared. The constituents of the Minor Element Solution were $0.04 \mathrm{~g}$ Sodium borate $\left(\mathrm{Na}_{2} \mathrm{BO}_{7} .2 \mathrm{H}_{2} \mathrm{O}\right) ; 0.8 \mathrm{~g}$ Ferrous sulphate $\left(\mathrm{FeSO}_{4} .7 \mathrm{H}_{2} \mathrm{O}\right) ; 0.4 \mathrm{~g}$ Calcium sulphate $\left(\mathrm{CaSO}_{4} .5 \mathrm{H}_{2} \mathrm{O}\right) ; 0.8 \mathrm{~g}$ Manganese sulphate $\left(\mathrm{MnSO}_{4} .4 \mathrm{H}_{2} \mathrm{O}\right) ; 0.08 \mathrm{~g}$ Sodium molybdate $\left(\mathrm{Na}_{2} \mathrm{Mn}_{4} .2 \mathrm{H}_{2} 0\right)$; $0.08 \mathrm{~g}$ Zinc sulphate $\left(\mathrm{ZnSO}_{4} .7 \mathrm{H}_{2} \mathrm{O}\right)$; and $1000 \mathrm{ml}$ sterile distilled water.

A volume of $30 \mathrm{ml}$ of the synthetic basal medium was dispensed into 16 250-ml Erlenmeyer flasks, and separated into four lots. Thiamine was excluded from lot 1 to serve as the control; 100 $\mu \mathrm{g} / \mathrm{L}, 200 \mu \mathrm{g} / \mathrm{L}$, and $400 \mu \mathrm{g} / \mathrm{L}$ aliquots of thiamine solutions were added to lots 2,3 and 4 , respectively. Since thiamine is unstable when heated in an alkaline medium, an aqueous solution of the vitamin was prepared separately, the $\mathrm{pH}$ adjusted to 5.0 , autoclaved at a pressure of $1.1 \mathrm{~kg} / \mathrm{cm}^{2}$ at $121^{\circ} \mathrm{C}$ for 15 minutes, and $1 \mathrm{ml}$ was added to the sterile basal media aseptically. The thiamineamended basal synthetic media dispensed into the 250-ml Erlenmeyer flasks, in triplicates for each concentration, were inoculated with a $3-\mathrm{mm}$ culture disc of $A$. niger strain AN1, incubated at $30^{\circ} \mathrm{C}$ for 8 days and harvested to determine dry weight of mycelia. The initial and final $\mathrm{pH}$ levels of each culture were recorded. The experiment was repeated using A. niger strains AN2, AN3 and AN4.

\section{Determination of vegetative growth of $A$. niger strains on media with different concentrations of ammonium nitrate}

Four lots of 1-L synthetic basal media were prepared, after which $1.0 \mathrm{~g}, 2.0 \mathrm{~g}, 3.0 \mathrm{~g}$, and $4.0 \mathrm{~g}$ of ammonium nitrate were respectively added to lot 1, 2, 3 and 4 . A volume of $30 \mathrm{ml}$ aliquots of the basal medium supplemented with $1 \mathrm{~g}$ ammonium nitrate from lot 1 was dispensed into $250 \mathrm{ml}$ Erlenmeyer flasks, in triplicates, inoculated with a 3-mm culture disc of $A$. niger strain AN1, incubated at $30^{\circ} \mathrm{C}$ for 8 days and harvested to determine dry weight of mycelia. The initial and final $\mathrm{pH}$ of each culture were recorded. The experiment was repeated using A. niger strains AN2, AN3 and AN4.

\section{Assessment of vegetative growth of $A$. niger strains on media with different concentrations of sodium chloride}

The effect of sodium chloride on the growth and sporulation of A. niger strains was investigated 
using four lots of 1-L PDB medium. Masses of 1, 2, 4, and $8 \mathrm{~g}$ of sodium chloride were added to lot 1, 2,3 and 4, respectively, and autoclaved at a pressure of $1.1 \mathrm{~kg} / \mathrm{cm}^{2}$ at $121^{\circ} \mathrm{C}$ for 15 minutes. A volume of 30-ml aliquots of the PDB medium amended with $1 \mathrm{~g}$ sodium chloride from lot 1 was dispensed into 250-ml Erlenmeyer flasks, in triplicates, inoculated with a 3-mm culture disc of AN1 strain raised on plain water agar medium, incubated at $30^{\circ} \mathrm{C}$ for 8 days and harvested to determine dry weight. The initial and final $\mathrm{pH}$ of each culture were recorded. The experiment was repeated using the other $A$. niger strains - AN2, AN3 and AN4.

\section{Estimation of Protein Content of Cassava}

The periderm and cortex of the cassava tubers (peelings) were removed, the white starchy flesh was washed, cut into small pieces and milled into a thick, malleable mixture of flour and liquid (dough). A substantial amount of distilled water was added to the dough and thoroughly stirred to obtain uniform slurry. Small quantities of the slurry were poured into clean cheesecloth and pressed to extract the starch content. The resultant cassava pulp was air-dried to constant weight, and stored at $4^{\circ} \mathrm{C}$ until ready to use. One batch of $10250-\mathrm{ml}$ Erlenmeyer flasks each containing $100 \mathrm{~g}$ of cassava pulp was autoclaved at a pressure of $1.1 \mathrm{~kg} / \mathrm{cm}^{2}$ at $121^{\circ} \mathrm{C}$ for 15 minutes (sterile cassava pulp) and supplemented with sterile synthetic basal medium that contained the right concentrations of thiamine, ammonium nitrate, and sodium chloride, based on results obtained from the nutritional requirements studies; the other batch of 10 flasks each containing $100 \mathrm{~g}$ of cassava pulp was not autoclaved (nonsterile cassava pulp), but were also supplemented with sterile synthetic basal medium as was applied to the sterile cassava pulp. The $\mathrm{pH}$ of the cassava pulps was adjusted with McIlvaine (1921) stock buffer solution to 5.0. The moisture content of the cassava pulp was maintained at $50 \% \mathrm{w} / \mathrm{v}$.

Initial percentage nitrogen $\left(\% \mathrm{~N}_{2}\right)$ contents of 5 sterile and 5 non-sterile cassava pulps were determined by the Kjeldahl method (Kjeldahl 1883). The remaining 5 flasks of both sterile and nonsterile cassava pulps were then inoculated with spore suspensions of $A$. niger strain AN1 and incubated at $30^{\circ} \mathrm{C}$ in a static position. $\mathrm{N}_{2}$ contents $(\%)$ of samples from the sterile and non-sterile cassava pulps were determined after 4 and 8 days of fermentation. The $\mathrm{N}_{2}$ contents of both the sterile and non-sterile cassava pulp thus determined were subsequently used to estimate the percentage protein (\% Protein) content of samples as follows:

$$
\% \text { Protein Content }=\% \mathrm{~N}_{2} \times 6.25 \text {, }
$$

where 6.25 is the protein conversion factor.

Percentage increase in protein content of sterile and non-sterile cassava samples was determined using the expression,

\section{Final Protein Content - Initial Protein Content X 100\%}

Initial Protein Content

The experimental procedure was repeated for A. niger strains AN2, AN3 and AN4.

\section{Results}

\section{Linear Mycelial Growth}

There was a linear mycelial growth among the four A. niger strains being $2.1-8.1 \mathrm{~cm}$ for AN1, $2.3-7.8 \mathrm{~cm}$ for AN2, $2.1-8.3 \mathrm{~cm}$ for AN3, and 2.2 - $8.2 \mathrm{~cm}$ for AN4 (Fig. 1). All the strains grew longer after day 2 of inoculation and incubation, and sustained their growth during the experiment. Although AN2 had the longest initial growth of $2.3 \mathrm{~cm}$ at day 2, its mycelia were the shortest $(7.8 \mathrm{~cm})$ at day 10 compared to the other strains. A. niger strain AN3 had the longest mycelia growth of $8.3 \mathrm{~cm}$ 
at day 10 (Fig. 1).

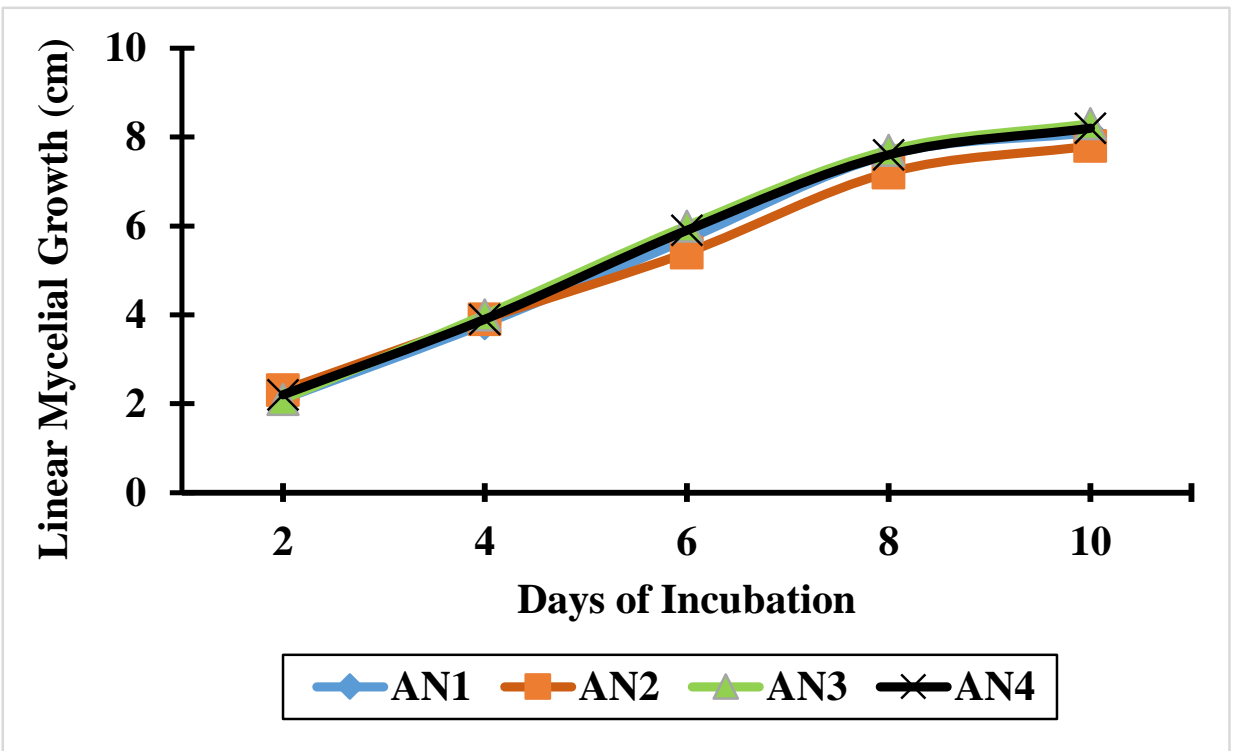

Fig. 1 - Linear growth of mycelia of A. niger strains on Potato Dextrose Agar. AN1 - A. niger strain 1; AN2 - A. niger strain 2; AN3 - A. niger strain 3; AN4 - A. niger strain 4.

Mycelial dry weight of $\boldsymbol{A}$. niger strains cultured on potato dextrose broth at different $\mathbf{p H}$

All the growth media supported mycelial growth and the mycelial dry weight of the four A. niger strains varied at different $\mathrm{pH}$ levels. The highest mycelial dry weight of $173.3 \pm 6.7 \mathrm{mg}$ at $\mathrm{pH}$ of 4 was recorded for AN1, whereas both AN2 and AN3 had the lowest mycelial dry weight of $63.3 \pm 3.3 \mathrm{mg}$ at pH of 10. Growth media adjusted with Clark \& Lubs (1917a, 1917b, 1917c) buffer stock solutions resulted in remarkably reduced mycelial dry weight among the four strains compared to those adjusted with McIlvaine (1921) buffer stock solutions (Tables 1, 2, 3 and 4). Final pH of all media indicates that the growth of $A$. niger strains was supported in more acidic media.

Table 1 Dry weight of mycelia of $A$. niger strain AN1 cultured on potato dextrose broth adjusted with stock buffer solutions to different $\mathrm{pH}$ at $30^{\circ} \mathrm{C}$ for 8 days.

\begin{tabular}{lll}
\hline McIlvaine Buffer Solution & & \\
Initial pH & Final pH of Culture Filtrate & Mean Mycelium Dry Weight (mg) \pm S.E. \\
\hline 4.0 & 2.2 & $173.3 \pm 6.7$ \\
5.0 & 2.4 & $168.0 \pm 5.8$ \\
6.0 & 2.4 & $170.0 \pm 10.0$ \\
7.0 & 2.3 & $169.0 \pm 3.3$ \\
8.0 & 2.7 & $170.0 \pm 6.0$ \\
\hline & & \\
Clark and Lubs Buffer Solution & & $136.6 \pm 18.0$ \\
\hline 9.0 & 3.0 & $80.0 \pm 10.0$ \\
\hline
\end{tabular}


Table 2 Dry weight of mycelia of $A$. niger strain AN2 cultured on potato dextrose broth adjusted with stock buffer solutions to different $\mathrm{pH}$ at $30^{\circ} \mathrm{C}$ for 8 days.

\begin{tabular}{lll}
\hline McIlvaine Buffer Solution & & \\
Initial pH & Final pH of Culture Filtrate & Mean Mycelium Dry Weight (mg) \pm S.E. \\
\hline 4.0 & 2.3 & $143.3 \pm 3.3$ \\
5.0 & 2.6 & $153.3 \pm 3.3$ \\
6.0 & 3.0 & $153.3 \pm 6.7$ \\
7.0 & 2.4 & $160.0 \pm 10.0$ \\
8.0 & 2.5 & $160.0 \pm 5.8$ \\
\hline & & \\
\hline Clark and Lubs Buffer Solution & & $106.6 \pm 3.3$ \\
9.0 & 2.8 & $63.3 \pm 12.0$ \\
\hline
\end{tabular}

Table 3 Dry weight of mycelia of $A$. niger strain AN3 cultured on potato dextrose broth adjusted with stock buffer solutions to different $\mathrm{pH}$ at $30^{\circ} \mathrm{C}$ for 8 days.

\begin{tabular}{lll}
\hline McIlvaine Buffer Solution & & \\
Initial pH & Final pH of Culture Filtrate & Mean Mycelium Dry Weight (mg) \pm S.E. \\
\hline 4.0 & 2.6 & $140.0 \pm 10.0$ \\
5.0 & 2.8 & $138.3 \pm 13.3$ \\
6.0 & 2.8 & $140.0 \pm 5.8$ \\
7.0 & 3.0 & $140.6 \pm 3.3$ \\
8.0 & 3.2 & $140.0 \pm 5.8$ \\
\hline & & \\
\hline Clark and Lubs Buffer Solution & & $73.3 \pm 3.3$ \\
9.0 & 3.0 & $63.3 \pm 3.3$ \\
\hline
\end{tabular}

Table 4 Dry weight of mycelia of A. niger strain AN4 cultured on potato dextrose broth adjusted with stock buffer solutions to different $\mathrm{pH}$ at $30^{\circ} \mathrm{C}$ for 8 days.

\begin{tabular}{lll}
\hline McIlvaine Buffer Solution & & \\
Initial pH & Final pH of Culture Filtrate & Mean Mycelium Dry Weight (mg) \pm S.E. \\
\hline 4.0 & 2.8 & $143.3 \pm 3.3$ \\
5.0 & 3.0 & $136.6 \pm 3.3$ \\
6.0 & 2.7 & $136.6 \pm 3.3$ \\
7.0 & 2.8 & $136.6 \pm 3.3$ \\
8.0 & 3.2 & $130.0 \pm 5.8$ \\
\hline & & \\
\hline Clark and Lubs Buffer Solution & 3.4 & $93.3 \pm 3.3$ \\
9.0 & 4.5 & $86.6 \pm 3.3$ \\
\hline
\end{tabular}

Dry weight of mycelia of $A$. niger strains cultured on synthetic liquid medium supplemented with different concentrations of thiamine

Results from this experiment show that, although synthetic medium without thiamine (the control 
medium) supported growth of all strains of $A$. niger, synthetic media supplemented with varying concentrations of thiamine comparatively supported even more growth, especially in strains AN1, AN2 and AN4 at concentrations of $200 \mu \mathrm{g} / \mathrm{L}$ and $400 \mu \mathrm{g} / \mathrm{L}$ (Fig. 2). Interestingly, AN2 recorded a remarkably high dry weight of mycelia of $256.0 \mathrm{mg}$ at concentration of $400 \mathrm{ug} / \mathrm{L}$, compared to AN1, AN4 and AN3 which recorded respective dry weights of $236.0 \mathrm{mg}, 213.0 \mathrm{mg}$, and $163.3 \mathrm{mg}$ (Fig. 2). Final $\mathrm{pH}$ of all media indicates that the $A$. niger strains thrived in more acidic growth media.

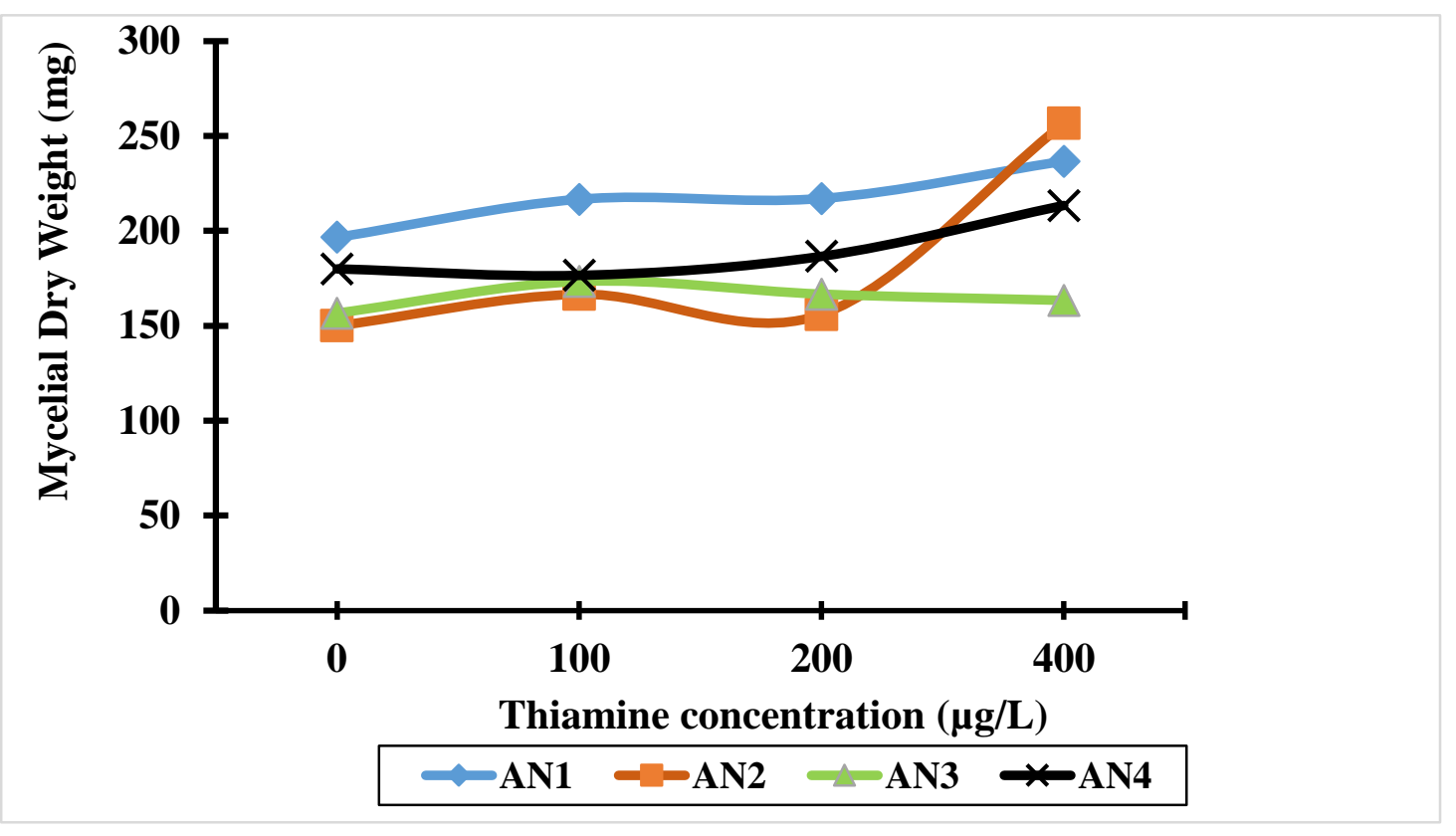

Fig. 2 - Dry weight of mycelia of $A$. niger strains cultured on synthetic basal medium supplemented with different concentrations of thiamine. AN1 - A. niger strain 1; AN2 - A. niger strain 2; AN3 - A. niger strain 3; AN4 - A. niger strain 4.

Dry weight of mycelia of $A$. niger strains cultured on synthetic basal medium amended with different concentrations of ammonium nitrate

Fig. 3 shows that ammonium nitrate generally supported the growth of all the A. niger strains. Maximum dry weight of mycelia of all $A$. niger strains was achieved with ammonium nitrate at a concentration of $2.0 \mathrm{~g} / \mathrm{L}$. Concentrations above this resulted in reduced growth. Final $\mathrm{pH}$ of all media indicate that the $A$. niger strains thrived in more acidic growth media.

\section{Dry weight of mycelia of $A$. niger strains cultured on potato dextrose broth supplemented with different concentrations of sodium chloride}

PDB supplemented with different concentrations of sodium chloride supported growth of $A$. niger strains to varying degrees. PDB growth medium supplemented with $8.0 \mathrm{~g}$ of sodium chloride resulted in the highest mycelial dry weight production for all A. niger strains (Fig 4.). Additionally, the extent of sporulation, based on observation, varied remarkably among the strains. Sporulation was moderate in AN1, sparse in AN2, and high in AN3 and AN4. Final pH of all media indicated that the A. niger strains thrived better in more acidic growth media.

\section{Protein enrichment of fermented sterile and non-sterile cassava pulp}

Protein content of sterile and non-sterile cassava pulp fermented for 8 days steadily increased and varied among the $A$. niger strains. Percentage increases in protein contents of sterile cassava pulp 
by AN1, AN2, AN3 and AN4 were 15.65\%, 22.61\%, 18.30\% and 19.13\%, respectively (Fig. 5). The percentage increase in protein contents of non-sterile cassava pulp by AN1, AN2, AN3 and AN4 were $15.40 \%, 21.54 \%, 10.80 \%$ and $3.85 \%$, respectively (Fig. 6).

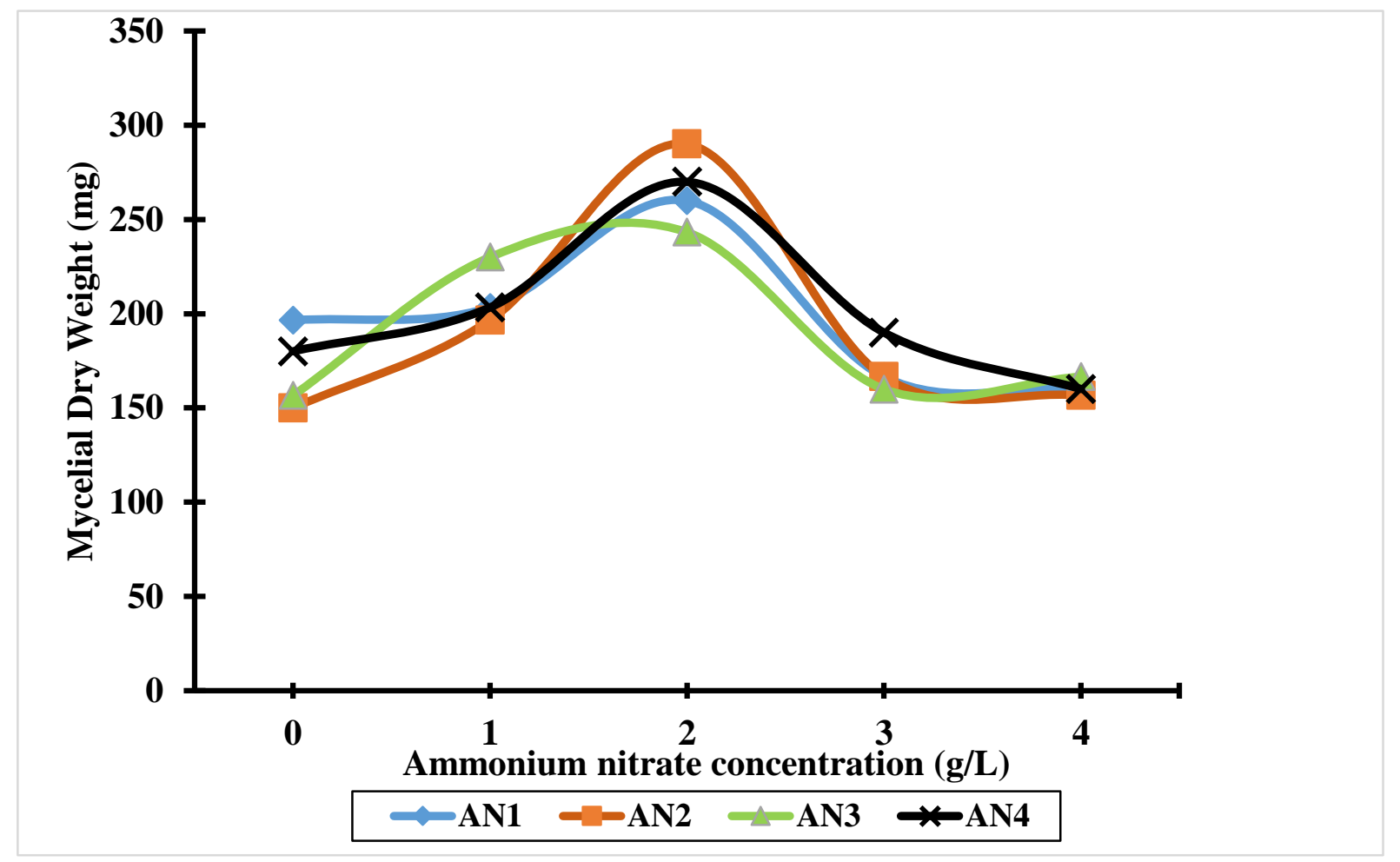

Fig. 3 - Dry weight of mycelia of $A$. niger strains cultured on synthetic basal medium supplemented with different concentrations of ammonium nitrate. AN1 - A. niger strain 1; AN2 - A. niger strain 2;AN3 - A. niger strain 3; AN4 - A. niger strain 4.

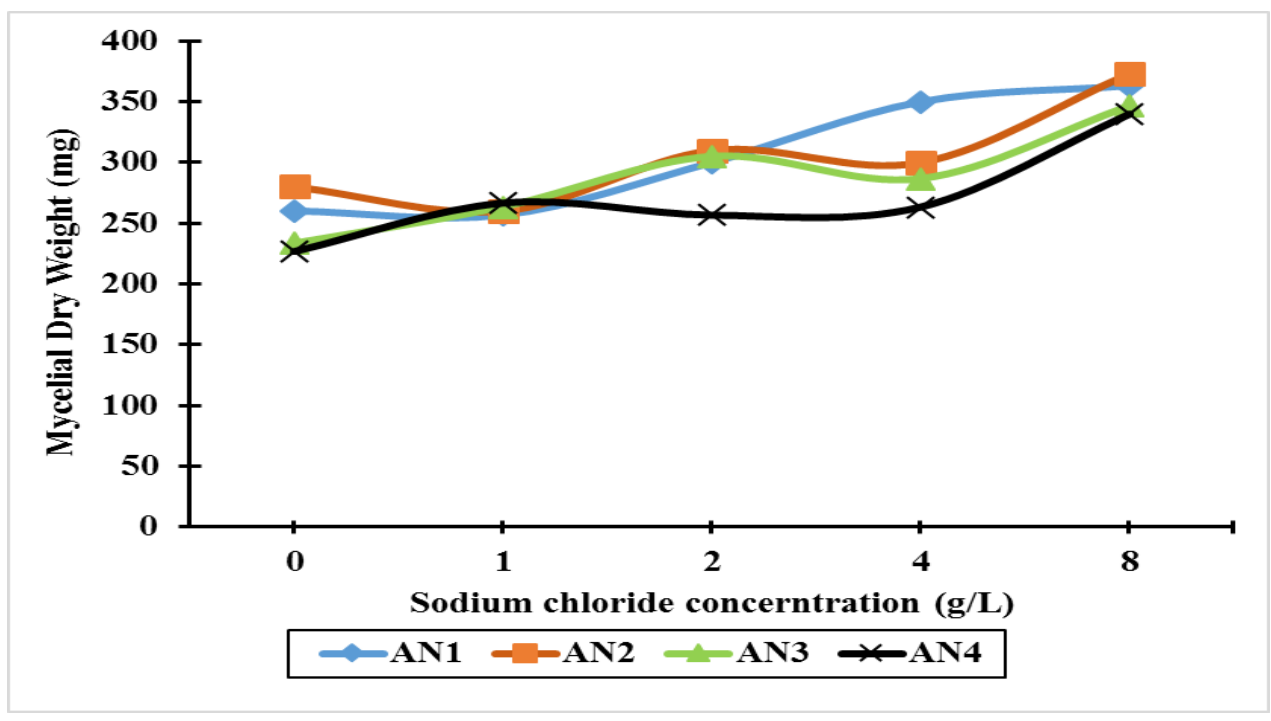

Fig. 4 - Dry weight of mycelia of $A$. niger strains cultured on potato dextrose broth supplemented with different concentrations of sodium chloride. AN1 - A. niger strain 1; AN2 - A. niger strain 2; AN3 A. niger strain 3; AN4 - A. niger strain 4. 


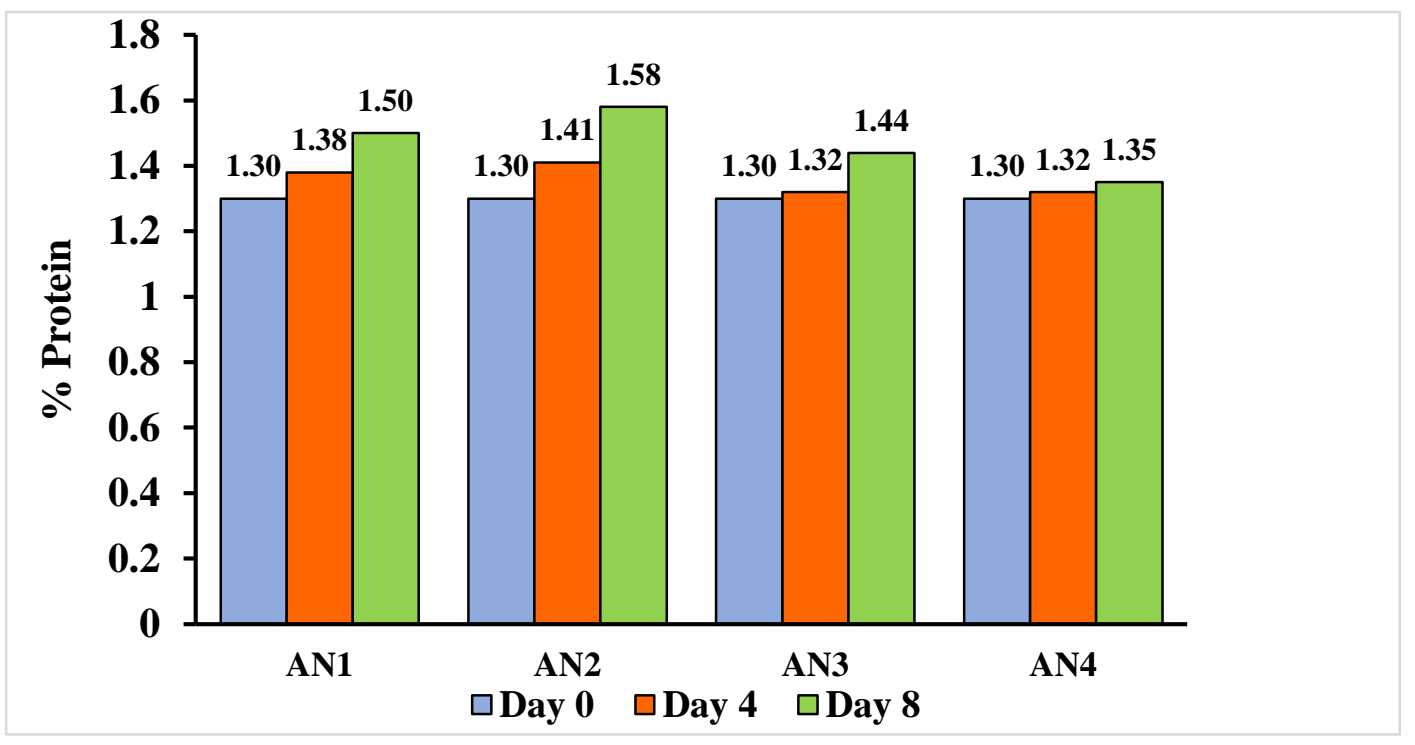

Fig. 5 - Percentage protein contents of sterile cassava pulp after solid-state fermentation with A. niger strains. AN1 - A. niger strain 1; AN2 - A. niger strain 2; AN3 - A. niger strain 3; AN4 - A. niger strain 4.

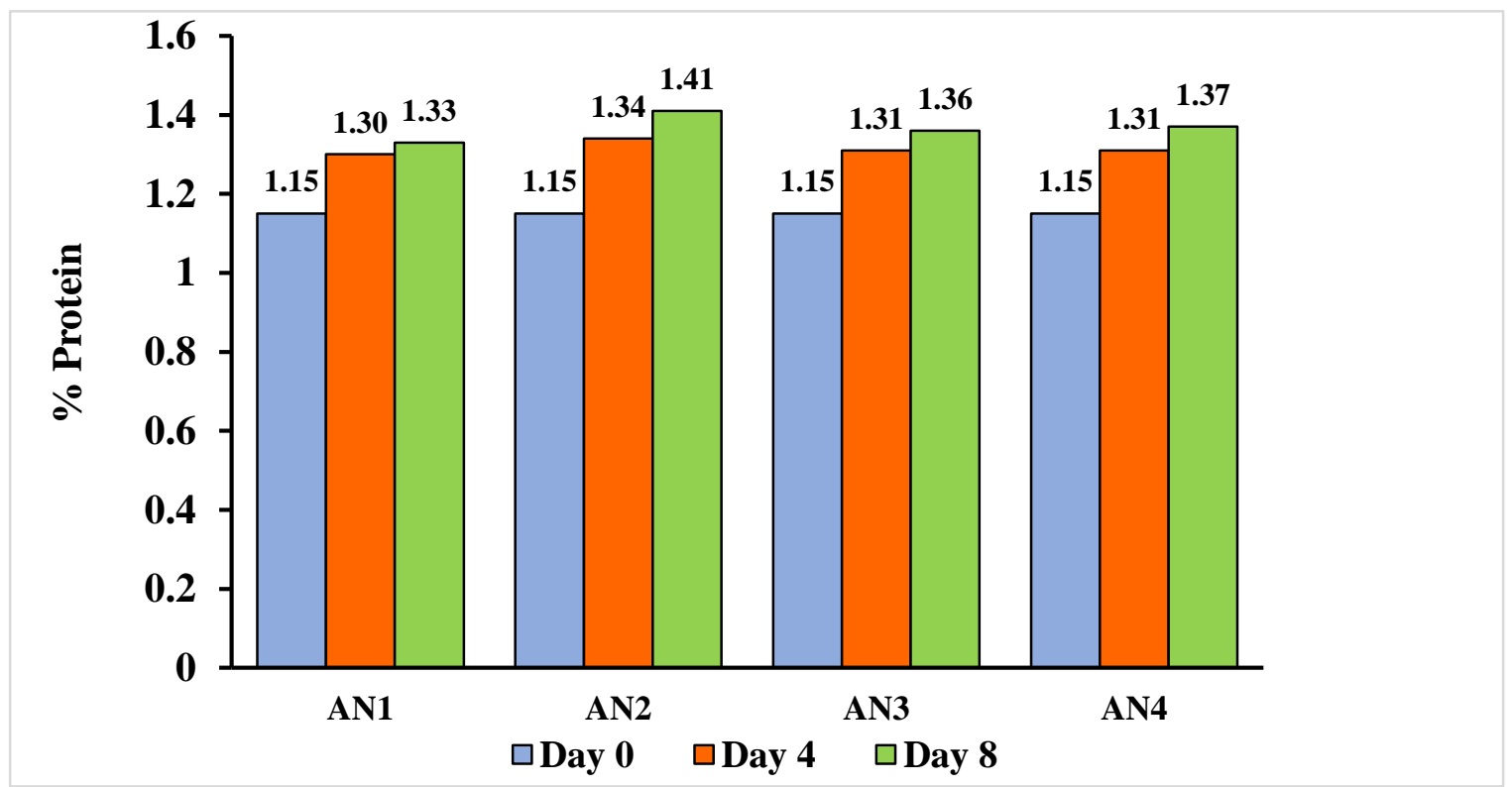

Fig. 6 - Percentage protein contents of non-sterile cassava pulp after solid-state fermentation with $A$. niger strains. AN1 - A. niger strain 1; AN2 - A. niger strain 2; AN3 - A. niger strain 3; AN4 - A. niger strain 4.

\section{Discussion}

Findings from this study show that growth of A. niger strains was variously supported in synthetic liquid media supplemented with thiamine, ammonium nitrate and sodium chloride at different $\mathrm{pH}$ levels. These results provide insights into the nutritional requirements for growth and sporulation in A. niger strains, and their suitability for solid-state fermentation of sterile and non-sterile cassava pulp. In this study, it was revealed that PDB growth medium supplemented with various 
quantities of sodium chloride supported growth of the A. niger strains, and with varying degrees of sporulation. The highest growth was recorded for $A$. niger strain AN2, which also sparingly produced spores, compared to A. niger strains AN1, AN3 and AN4 that moderately or heavily produced spores. This presents $A$. niger strain AN2 as the most suitable candidate that could be used to enrich the protein content of cassava pulp through solid-state fermentation. Mitchell et al. (1988) reported that sodium chloride concentrations above $0.5 \%$ inhibited growth of Rhizopus bisporus, whereas growth in Aspergillus oryzae was unaffected up to $4 \%$ sodium chloride. Findings by Tsen et al. (2000), Gao et al. (2007), Gao and Liu (2010), Gao (2014) also shed more light on the nutritional requirements of fungi in relation to mycelial growth and sporulation.

In this study cassava pulp served as the carbon source for growth in A. niger. Balagopalan (1996) reported a remarkable decrease in starch in cassava residue over a period of 12 days, further suggesting that fungi, indeed, utilize a wide range of carbon sources (monosaccharides, disaccharides and polysaccharides) for mycelial growth (Nagadesi \& Arya 2013). Panday et al. (2000) also reviewed the potential of sugarcane bagasse as an important carbon source.

The utilization of nitrogen sources by fungi during growth is critical to increasing protein contents of agro-industrial wastes. A study by Bayitse et al. (2015) showed that exogenous supply of nitrogen sources enhanced protein enrichment of cassava during fermentation with Trichoderma pseudokoningii. Similarly, reports by Roussos et al. (1993), Duru and Uma (2003) and Ezekiel and Aworh (2013) have supported the effective utilization of nitrogen sources, such as urea in Aspergillus oryzae and ammonium sulphate in Trichoderma viride. In this study, it was demonstrated that ammonium nitrate also supported growth of $A$. niger strains.

Findings from this study demonstrate that the protein contents of sterile fermented cassava pulp could be enriched using $A$. niger since, after 8 days, protein contents increased by $22.61 \%$, while those of non-sterile fermented cassava pulp was enriched by $21.54 \%$ when the substrates were kept at a moisture content of $50 \% \mathrm{w} / \mathrm{v}$. These findings compare with others that have been reported earlier. For example, studies of protein enrichment with other agro-industrial residues, such as cassava peel, cocoyam, orange peels and pineapples, have been conducted using Aspergillus oryzae, Aspergillus niger, Rhizopus oryzae, and Saccharomyces cerevisiae (Duru \& Uma 2003, Ezekiel \& Aworh 2013, Handy 2013, Aggelopoulos et al. 2014). Bayitse et al. (2015) in their work reported a maximum of $36.9 \%$ and $48.1 \%$ protein enrichment of cassava waste, after 12 days of fermentation, when urea and ammonium sulphate were, respectively, used as nitrogen sources. Iyayi and Losel (2001) also reported percentage increase in protein content of cassava peels between 5.6 and $14.4 \%$ when A. niger was used under conditions of solid-state fermentation for 20 days; the use of $S$. cerevisiae resulted in a percentage increase of $16.74 \%$ in protein content of cassava peels. Ezekiel and Aworh (2013) further demonstrated that $T$. pseudokoningii enriched cassava peels better with protein than T. viride.

This study on the protein enrichment of cassava pulp under conditions of solid-state fermentation by $A$. niger add to the relatively scant literature available in Ghana on the biotechnological applications of fungi for improved nutritional and economic values of large quantities of agro-industrial wastes. Future studies should be directed at using other filamentous fungi for protein enrichment of agroindustrial wastes from coffee (Coffea arabica), maize (Zea mays), oil palm (Elaeis guineensis), pineapple (Ananas sativa), potato (Ipomoea batatas), sugarcane (Saccharum officinarum), rubber (Hevea brasiliensis), plantain and banana (Musa spp), and watermelon (Citrillus lanatus). Findings from such studies should enhance understanding of the application of fungal species in protein enrichment of agro-industrial wastes that could serve as feed for poultry and fish. Not only would these feed productions enhance the economic earnings of peasant farmers, they would also make protein available for human consumption.

\section{Acknowledgments}

Many thanks to Department of Nutrition and Food Science, University of Ghana, for allowing 
the use of the Kjeldahl apparatus for protein analyses. The technical assistance provided by the technical staff of the Department of Botany and the Department of Nutrition and Food Science of the University of Ghana is gratefully acknowledged.

\section{References}

Aggelopoulos T, Katsieris K, Bekatorou A, Pandey A, Banat IM, Koutinas AA. 2014 - Solid state fermentation of food waste mixtures for single cell protein, aroma volatiles and fat production. Food Chemistry 145, 710-6.

Agosin D, Jarpa S, Rojas E, Espejo E. 1989 - Solid state fermentation of pine sawdust by brown-rot fungi. Enzyme and Microbial Technology 11, 511-517.

Akinrele IA. 1967 - Further studies on the fermentation of cassava. Research. Report No.20 of the Federal Institute of Industrial Research, Oshodi, Nigeria.

Balagopalan C. 1996 - Improving the nutritional value of cassava by solid state fermentation: CTCRI experiences. Journal of Scientific and Industrial Research 5, 479-482.

Bayitse R, Oduro W, Aggey M, Selormey G, Mensah B, Laryea G. 2013 - Overview of potential biowaste and biobased residues for production of value added products. Ghana Country Report for FP7 Biowaste4SP, Grant Agreement No. 312111.

Bayitse R, Hou X, Laryea G, Bjerre A-B. 2015 - Protein enrichment of cassava residue using Trichoderma pseudokoningii (ATCC 26801). AMB Express 5, 80-85.

Clark WM, Lubs HA. 1917a - The colorimetric determination of hydrogen ion concentration and its application in bacteriology: I. Journal of Bacteriology, 2(1), 1-34.

Clark WM, Lubs HA. 1917b - The colorimetric determination of hydrogen ion concentration and its application in bacteriology: II. Journal of Bacteriology, 2(2), 109-136.

Clark WM, Lubs HA. 1917c - The colorimetric determination of hydrogen ion concentration and its application in bacteriology: III. Journal of Bacteriology, 2(3), 191-236.

Correia R, Magalhães M, Macêdo G. 2007 - Protein enrichment of pineapple waste with Saccharomyces cerevisiae by solid state bioprocessing. Journal of Scientific and Industrial Research 66, 259-262.

Duru CC, Uma NU. 2003 - Protein enrichment of solid waste from cocoyam (Xanthosoma sagittifolium) (L.) (Schott) cormel processing using Aspergillus oryzae obtained from cormel flour. African Journal of Biotechnology 2(8), 228-232.

Ezekiel OO, Aworh OC. 2013 - Solid State Fermentation of Cassava Peel with Trichoderma viride (ATCC 36316) for Protein Enrichment. International Journal of Nutrition and Food Engineering 7(3), 202-209.

Gao L, Sun MH, Liu XZ, Che YS. 2007 - Effects of carbon concentration and carbon to nitrogen ratio on the growth and sporulation of several biocontrol fungi. Mycological Research 111(1), 87-92.

Gao L, Liu X. 2010 - Nutritional requirements of mycelial growth and sporulation of several biocontrol fungi in submerged and on solid culture. Microbiology 79, 612-619.

Gao L. 2014 - A preliminary study on nutritional requirements of nematophagous fungus ARF907 for mycelial growth. Journal of Yeast and Fungal Research 5(7), 92-95.

Gélinas P, Barrette J. 2007 - Protein enrichment of potato processing waste through yeast fermentation. Bioresource Technology 98(5), 1138-1143.

Grace MR. 1977 - Cassava processing. FAO Plant Production and Protection Series No 3.

Handy HS. 2013 - Production of mini-food by Aspergillus niger, Rhizopus oryzae and Saccharomyces cerevisiae using orange peels. Romanian Biotechnological Letters. 18, 7929-7946.

Iyayi EA, Losel DM. 2001 - Protein enrichment of cassava by-products through solid state fermentation by fungi. Journal of Food Technology in Africa 6(4), 116-118. 
Kjeldahl J. 1883 - "Neue Methode zur Bestimmung des Stickstoffs in organischen Körpern" (New method for the determination of nitrogen in organic substances), Zeitschrift für Analytische Chemie 22, 366-382.

Kumar PKR. 1987 - Microbial production of gibberellic acid. PhD Thesis, Mysore University, Mysore, India.

McIlvaine TC. 1921 - A buffer solution for colorimetric comparison. Journal of Biological Chemistry 49, 183-186.

Mitchell DA, Doelle HW, Greenfield PF. 1988 - Agar plate growth studies of Rhizopus oligosporus and Aspergillus oryzae to determine their suitability for solid state fermentation. Applied Microbiology and Biotechnology 28, 598-602.

Nagadesi PK, Arya A. 2013 - Effect of carbon and nitrogen on the growth of lignicolous fungi from Rathanmahal Wildlife Sanctuary. International Journal of Science and Nature 4(2), 237-245.

Onilude A. 1996 - Effect of cassava cultivar, age and pretreatment processes of cellulase and xylanase production from cassava waste by Trichoderma harzanium. Journal Basic Microbiology 36, 42131.

Oriol E, Schettino B, Viniegra-Gonzalez G, Raimbault M. 1988a - Solid state culture of Aspergillus niger on support. Journal of Fermentation Technology 66, 57-62.

Panday A, Soccol CR. 2000 - Economic utilization of crop residues for value addition: a futuristic approach. Journal of Science and Industrial Research 59(1), 12-22.

Panday A, Soccol CR, Nigam P, Soccol VT. 2000 - Biotechnological potential of agro-industrial residues. I: sugarcane bagasse. Bioresource Technology 74, 69-80.

Roussos S, Raimbault M, Prébois JP, Losane BK. 1993 - Zymotis, large scale solid state fermenter: design and evaluation. Applied Biochemistry and Biotechnology 42, 37-52.

Soccol CR, Vandenberghe LPS. 2003 - Overview of applied solid-state fermentation in Brazil. Biochemical Engineering Journal 13, 205-218.

Tengerdy RP. 1985 - Solid substrate fermentation. Trends in Biotechnology 3, 96-99.

Tsen YY, Chen MT, Lin CF. 2000 - Growth, pigment production and protease activity of Monascus purpureus as affected by salt, sodium nitrate, polyphosphate and various sugars. Journal of Applied Microbiology 88, 31-37. 